\title{
Kemampuan Berpikir Kritis Peserta Didik Melalui Pembelajaran Talking Stick dengan Media Pohon Matematika Pada Materi Operasi Hitung Bilangan Bulat
}

\author{
Rahmah Kumullah $^{1 凶} \&$ Ahmad Yulianto $^{2}$
}

\author{
Program Studi PGSD, STKIP Andi Matappa, Indonesia \\ Program Studi PGSD, Universitas Pendidikan Muhammadiyah sorong, Indonesia \\ ${ }^{凶}$ E-mail: rahmahkumullah71@gmail.com
}

\begin{abstract}
Abstrak
Penelitian ini bertujuan untuk meningkatkan kemampuan berpikir kritis melalui penggunaan model pembelajaran kooperatif tipe talking stick berbantuan media pohon matematika. Jenis penelitian ini merupakan Penelitian Tindakan Kelas. Subjek penelitian ini adalah peserta didik kelas V SDN 23 Tanete sebanyak 18 orang. Penelitian ini dilakukan dalam dua siklus dengan setiap siklus terdiri dari empat pertemuan. Tekhnik pengumpulan data berupa tes hasil belajar, observasi kegiatan guru dan peserta didik, dan dokumentasi. Hasil penelitian menunjukkan bahwa rata-rata hasil tes kemampuan berpikir kritis peserta didik pada siklus I sebesar 69,14\% dan meningkat signifikan pada siklus II sebesar $86,53 \%$. Selanjutnya, rata-rata hasil tes kemampuan berpikir kritis peserta didik dari hasil evaluasi akhir siklus I sebesar 60,42\% meningkat signifikan pada siklus II sebesar $88,00 \%$. Selain itu, terdapat pula rata-rata perolehan aktivitas guru dan peserta didik juga meningkat setiap tindakan dari setiap siklus pada siklus I dan II yaitu rata-rata aktivitas guru dalam pembelajaran pada siklus I sebesar $67,95 \%$ meningkat signifikan pada siklus II sebesar $89,10 \%$. Selanjutnya, rata-rata aktivitas peserta didik dalam pembelajaran pada siklus I sebesar 55,13\% meningkat signifikan pada siklus II sebesar $82,05 \%$. Hal ini menunjukkan adanya peningkatan kemampuan berpikir kritis melalui penggunaan model pembelajaran kooperatif tipe talking stick berbantuan media pohon matematika.
\end{abstract}

Kata Kunci: Talking Stick; Pohon Matematika; Berpikir Kritis.

\begin{abstract}
This study aims to improve the ability to think critically through the use of cooperative learning models talking stick type assisted by mathematical tree media. This type of research is Classroom Action Research. The subjects of this study were 18 students of class V SDN 23 Tanete. This research was conducted in two cycles with each cycle consisting of four meetings. Data collection techniques in the form of test results of learning, observation of teacher and student activities, and documentation. The results showed that the average test results of students' critical thinking skills in the first cycle amounted to $69.14 \%$ and increased significantly in the second cycle amounted to $86.53 \%$. Furthermore, the average test results of students' critical thinking skills from the evaluation results of the end of the first cycle of $60.42 \%$ increased significantly in the second cycle of $88.00 \%$. In addition, there is also an average acquisition of teacher and student activities also increasing each action of each cycle in cycles I and II, namely the average teacher activity in learning in the first cycle of $67.95 \%$ increased significantly in the second cycle of 89, 10\% Furthermore, the average activity of students in learning in the first cycle of $55.13 \%$ increased significantly in the second cycle of $82.05 \%$. This shows an increase in critical thinking skills through the use of cooperative learning models talking stick type assisted by mathematical tree media.
\end{abstract}




\section{PENDAHULUAN}

Observasi awal yang telah dilakukan ditemukan penggunaan model pembelajaran, namun belum digunakan secara sistematis sesuai dengan langkah model pembelajaran. Selain itu cenderung penyampaian materi dengan jalur komunikasi satu arah, meskipun jalur komunikasi satu arah yaitu dari guru ke peserta didik, hal itu bukan berarti metodenya yang salah, melainkan ketidakprofesionalan pengguna metode ceramah ketika menerapkan dalam pembelajaran di kelas (Purwanto, 2013: 77). Hal ini mengakibatkan peserta didik kurang aktif dalam pembelajaran matematika di kelas.

Hasil observasi pada peserta didik juga terlihat adanya indikator berpikir kritis yang dilakukan oleh peserta didik diantaranya adalah menemukan solusi atas pemecahan masalah soal latihan close ended. Soal latihan yang sifatnya close ended mengakibatkan peserta didik kurang berpikir kritis terhadap pemecahan soal yang sifatnya contoh, latihan soal, maupun soal evaluasi.

Pemilihan model dan media yang tepat diharapkan dapat meningkatkan kemampuan berpikir kritis peserta didik. Menurut Yulianto dkk, (2018) Penggunaan media merupakan salah satu faktor yang dapat membantu peserta didik dalam memahami materi. Karakteristik pembelajaran kooparatif adalah pembelajaran secara kelompok dengan anggota kelompok, kemauan untuk bekerjasama, dan keterampilan bekerjasama (Prastowo, 2013: 78-79). Menurut Subanji (2013: 158) pencapaian belajar optimal peserta didik dalam pembelajaran kooperatif dapat ditempuh apabila peserta didik mendapat bantuan orang dewasa yang lebih mahir dalam dirinya, orang dewasa itu adalah guru maupun peserta didik yang memiliki kelebihan pengalaman lebih banyak.

Guru mengatur dan memfasilitasi kegiatan belajar yang banyak melibatkan interaksi yang terjadi antar peserta didik sebagai konsekuensi dari belajar yang berpusat pada peserta didik (Wahidmuini, 2010: 130). Salah satu model pembelajaran kooperatif yang dapat mengatasi masalah berpikir kritis peserta didik adalah model pembelajaran kooperatif tipe talking stick. Model pembelajaran kooperatif tipe talking stick lebih mengedepankan keaktifan peserta didik dalam keterampilan memecahkan masalah, memahami materi pelajaran dengan cepat, serta mengkomunikasikannya kepada peserta didik yang lain (Huda, 2013: 225). Talking stick pada mulanya digunakan oleh penduduk asli Amerika untuk mengajar semua orang berbicara atau menyampaikan pendapat dalam suatu forum pada pertemuan antarsuku (Huda, 2013: 224-225) dengan langkah-langkah sebagai berikut: (1) guru menyiapkan sebuah tongkat yang panjangnya $\pm 20 \mathrm{~cm}$; (2) guru menyiapkan materi pokok yang akan dipelajari; (3) guru memberi kesempatan kepada kelompok untuk mempelajari kembali materi pelajaran yang telah disampaikan; (4) guru memberikan tugas kelompok untuk didiskusikan, anggota yang sudah mengerti lebih awal membantu teman kelompoknya untuk memecahkan permasalahan bersama; (5) peserta didik menutup buku pelajaran; (6) guru mengambil tongkat dan memberikannya kepada salah satu peserta didik; (7) sambil menyanyi peserta didik yang memegang tongkat harus menjawab pertanyaan secara tertulis dari guru, demikian seterusnya hingga seluruh peserta didik dapat pertanyaan dari guru; (8) peserta didik bersama dengan guru menyimpulkan materi pelajaran; (9) guru melakukan evaluasi tertulis; dan (10) menutup pelajaran.

Langkah keempat dari sintaks tersebut adalah guru memberikan tugas kelompok untuk didiskusikan. Anggota yang sudah mengerti lebih awal membantu teman kelompoknya untuk memecahkan permasalahan bersama. Pemberian tugas kelompok yang dapat menumbuhkan kemampuan berpikir kritis peserta didik, maka guru perlu memberikan kegiatan yang dapat memfasilitasi peserta didik aktif dalam pembelajaran. Kegiatan dapat dilakukan dengan penggunaan media pohon matematika. Kehadiran media memiliki kedudukan yang penting sesuai Permendikbud Nomor 103 tahun 2013 
tentang kerangka RPP yang mencakup diantaranya poin kedelapan yaitu media, alat dan sumber belajar. Penggunaan media yang tepat dan efektif dapat membuat proses pembelajaran berjalan lancar karena membuat peserta didik tertarik dan mudah memahami materi yang akan disampaikan pada pembelajaran. Tujuan dari penggunaan media adalah untuk memudahkan komunikasi antar peserta didik dan guru dalam proses pembelajaran (Smaldino, Lowter \& Russel, 2011: 7) serta sebagai alat bantu dalam proses pembelajaran (Sudjana, 2012: 99). Merumuskan fungsi media pembelajaran sebagai alat bantu untuk mewujudkan situasi pembelajaran yang efektif, yang penggunaannya harus searah dengan tujuan dan isi materi/bahan ajar, penggunaan media harus dibuat interaktif agar dapat menarik perhatian peserta didik, sehingga efektif dalam membantu meningkatkan kemampuan berpikir kritis peserta didik. Media pohon matematika adalah salah satu media yang dapat digunakan untuk mengembangkan penalaran peserta didik dalam pembelajaran (Subanji, 2013: 141). Pembelajaran dengan media pohon matematika, guru menyajikan pohon sebagai pokok bahasan, ranting sebagai jawaban atau masalah, jika ranting berisi jawaban, maka peserta didik mengkontruksi soal pada daunnya dan jika ranting berisi masalah yang syaratnya harus open ended, maka peserta didik mencari semua alternatif jawaban sebagai daunnya.

Penggunaan model pembelajaran kooperatif tipe talking stcik dengan bantuan media pohon matematika ini pada akhirnya diharapkan dapat meningkatkan kemampuan berpikir kritis peserta didik dalam pembelajaran matematika khususnya pada materi operasi hitung bilangan bulat. Cahyaningsih dan Anik (2014) memberikan sebuah definisi berpikir kritis adalah interprestasi dan evaluasi yang terampil dan aktif terhadap observasi dan komunikasi, informasi, dan argumentasi. Sejalan dengan yang dikemukakan oleh Kumullah (2018: 158) pada penelitiannya bahwa merumuskan dan mengevaluasi pendapat merupakan salah satu cara yang ditempuh oleh siswa menuju berpikir kritis. Pertukaran gagasan yang aktif didalam kelompok kecil tidak hanya menarik perhatian peserta didik tetapi juga dapat mempromosikan pemikiran kritis. Menurut Totten (dalam Gokhale, 2002) bahwa kerjasama dapat memberi kesempatan kepada peserta didik untuk terlibat dalam diskusi, bertanggung jawab terhadap pelajaran sehingga dengan begitu mereka menjadi pemikir yang kritis.

\section{METODE PENELITIAN}

Metode penelitian yang digunakan adalah penelitian tindakan kelas dilakukan untuk memperbaiki mutu praktik pembelajaran di kelas (Arikunto, 2016) dengan memaparkan data penelitian secara alamiah sesuai fakta di lapangan. Fokus penelitian tindakan kelas (PTK) ini adalah kemampuan berpikir kritis peserta didik meningkat setelah mengikuti proses pembelajaran pada materi operasi hitung bilangan bulat dengan menggunakan model pembelajaran kooperatif tipe talking stick berbantuan media pohon matematika. Rancangan penelitian ini menggunakan alur penelitian tindakan kelas Kemmis dan Mc. Taggart (Arikunto, 2016) meliputi: 1) perencanaan (planning); 2) pelaksanaan (action and observation); dan 3) refleksi (reflecting).

Subjek dalam penelitian ini adalah guru dan peserta didik kelas V SD Negeri 23 Tanete, dengan jumlah peserta didik terdiri dari 18 orang yang terdiri dari 5 orang lakilaki dan 13 orang perempuan. Topik penelitian yaitu operasi hitung pada bilangan bulat.

Data penelitian diperoleh dari pengumpulan data yang dilakukan berupa tes hasil belajar, observasi kegiatan guru dan peserta didik saat proses pembelajaran berlangsung, dan dokumentasi. Tes dilakukan untuk mengumpulkan informasi tentang berpikir kritis peserta didik dalam pembelajaran materi operasi hitung bilangan bulat. Tes dilaksanakan pada awal penelitian, pada akhir setiap tindakan, dan pada akhir penelitian. 


\section{HASIL DAN PEMBAHASAN}

Pelaksanaan pada siklus I terdiri atas 4 pertemuan, pertemuan pertama sampai ketiga merupakan pertemuan tindakan dan observasi berupa penerapan model pembelajaran kooperatif tipe talking stick berbantuan media pohon matematika. Sedangkan pertemuan keempat merupakan kegiatan evaluasi sebagai hasil akhir pembelajaran pada pertemuan pertama sampai ketiga. Soal-soal evaluasi yang diberikan adalah soal-soal evaluasi yang mengarahkan peserta didik untuk berpikir kritis karena soal-soalnya bersifat open ended serta soal-soal membutuhkan pengidentifikasian masalah, pengklarifikasian masalah, menganalisis fakta, memecahkan masalah dari hasil analisis, mengevaluasi, serta menginverensiasi untuk menarik suatu kesimpulan masalah yang telah ditemukan dalam memecahkan masalah yang diberikan pada lembar evaluasi tersebut.

Hasil observasi aktivitas guru diperoleh berdasarkan kegiatan pembelajaran setiap pertemuan dalam rangkaian kegiatan siklus I. Dalam pelaksanaanya, secara umum perolehan penilaian aktivitas guru dapat dikatakan baik diantaranya saat guru membuka pelajaran, saat guru memberi pertanyaan open ended saat bermain tongkat, serta refleksi pembelajaran. Pada pertemuan pertama sebagai hasil dari keterlaksanaan pembelajaran yang dilakukan oleh guru dalam menerapkan model pembelajaran kooperatif tipe talking stick berbantuan media pohon matematika dari hasil observasi teman sejawat diperoleh sebesar 59,62\%, pertemuan kedua sebesar $65,38 \%$, pertemuan ketiga sebesar $78,84 \%$. Pencapaian kriteria yang diperoleh guru secara keseluruhan pada siklus I dalam penerapan model pembelajaran kooperatif tipe talking stick berbantuan media pohon matematika sudah baik. Rata-rata keterlaksanaan dari aktivitas guru secara keseluruhan yaitu $67,95 \%$. Ratarata keterlaksanaan ini juga belum mencapai target yang telah ditentukan yaitu $75 \%$ aktivitas guru terlaksana dengan kriteria baik.

Hasil observasi dari kegiatan peserta didik pada siklus I dalam penerapan model pembelajaran kooperatif tipe talking stick berbantuan media pohon matematika diperoleh data pada setiap pertemuan yaitu pada pertemuan pertama sebesar $46,15 \%$, pertemuan kedua sebesar $57,69 \%$, pertemuan ketiga 61,54\%. Secara keseluruhan pencapaian kriteria yang diperoleh peserta didik dalam penerapan model pembelajaran kooperatif tipe talking stick berbantuan media pohon matematika masih cukup sehingga perlu ditingkatkan lagi. Meskipun demikian, beberapa aktivitas peserta didik yang sudah tampak adalah bertanggungjawab menyelesaikan soal yang diberikan guru saat peserta didik mendapat giliran tongkat berbicara, selain itu pada akhir pembelajaran beberapa peserta didik sudah memiliki keberanian untuk menyimpulkan pembelajaran. Keterlaksanaan pembelajaran dari aktivitas peserta didik rata-rata 55,13\%. Rata-rata keterlaksanaan ini belum mencapai target yang telah ditentukan yaitu $75 \%$ aktivitas peserta didik terlaksana dengan kriteria baik.

Hasil tes kemampuan berpikir kritis peserta didik dari siklus I dalam penerapan model pembelajaran kooperatif tipe talking stick berbantuan media pohon matematika diperoleh data pada setiap pertemuan yaitu pada pertemuan pertama sebesar 1,7 kriteria cukup kritis dengan rata-rata perolehan kriteria ketuntasan belajar 59,42\% kriteria cukup baik, pertemuan kedua sebesar 2,1 kriteria cukup kritis dengan rata-rata perolehan kriteria ketuntasan belajar 72,08\% kriteria baik, pertemuan ketiga 2,1 kriteria cukup kritis dengan rata-rata perolehan kriteria ketuntasan belajar $75,92 \%$ kriteria baik. Secara keseluruhan pencapaian kemampuan berpikir kritis peserta didik dari setiap pertemuan dan tes evaluasi akhir siklus pada siklus I yaitu mencapai rata-rata skor 1,9 kriteria cukup kritis dengan rata-rata perolehan kriteria ketuntasan belajar yaitu $66,96 \%$ kriteria baik.

Sama halnya dengan siklus I, pelaksanaan pada siklus II juga terdiri atas 4 pertemuan, pertemuan pertama sampai ketiga merupakan pertemuan tindakan dan 
observasi berupa penerapan model pembelajaran kooperatif tipe talking stick berbantuan media pohon matematika. Sedangkan pertemuan keempat merupakan kegiatan evaluasi sebagai hasil akhir pembelajaran pada pertemuan pertama sampai ketiga.

Selanjutnya, hasil observasi aktivitas guru diperoleh berdasarkan kegiatan pembelajaran setiap pertemuan dalam rangkaian kegiatan siklus II. Dalam pelaksanaanya, secara umum perolehan penilaian aktivitas guru dapat dikatakan sangat baik karena guru rata-rata telah melaksanakan langkah-langkah pembelajaran secara sistematis sesuai dengan rencana yang telah dipersiapkan. Pada pertemuan kelima sebagai hasil dari keterlaksanaan pembelajaran yang dilakukan oleh guru dalam menerapkan model pembelajaran kooperatif tipe talking stick berbantuan media pohon matematika dari hasil observasi teman sejawat diperoleh sebesar 84,62\%, pertemuan keenam sebesar 88,46\%, pertemuan ketujuh sebesar 94,23\%. Pencapaian kriteria yang diperoleh guru secara keseluruhan pada siklus II dalam penerapan model pembelajaran kooperatif tipe talking stick berbantuan media pohon matematika sudah sangat baik. Rata-rata keterlaksanaan dari aktivitas guru secara keseluruhan yaitu $89,10 \%$. Rata-rata keterlaksanaan ini telah mencapai target yang telah ditentukan yaitu $75 \%$ aktivitas guru terlaksana dengan kriteria baik.

Penilaian berdasarkan pengamatan dari tindakan-tindakan sesuai dengan penerapan model pembelajaran kooperatif tipe talking stick berbantuan media pohon matematika untuk meningkatkan kemampuan berpikir kritis peserta didik dapat dikatakan sangat baik. Pada setiap pertemuan diperoleh data yaitu pada pertemuan kelima sebesar $71,15 \%$, pertemuan keenam sebesar $82,69 \%$, pertemuan ketujuh $92,31 \%$. Secara keseluruhan pencapaian kriteria yang diperoleh peserta didik dalam penerapan model pembelajaran kooperatif tipe talking stick berbantuan media pohon matematika untuk meningkatkan kemampuan berpikir kritis menunjukkan kriteria sangat baik. Kekurangan-kekurangan temuan pada siklus I juga sudah tidak ditemukan lagi. Keterlaksanaan pembelajaran dari aktivitas peserta didik rata-rata $82,05 \%$. Rata-rata keterlaksanaan ini telah mencapai target minimal yang telah ditentukan yaitu $75 \%$ aktivitas peserta didik terlaksana dengan kriteria baik.

Hasil tes kemampuan berpikir kritis peserta didik dari siklus II dalam penerapan model pembelajaran kooperatif tipe talking stick berbantuan media pohon matematika untuk meningkatkan kemampuan berpikir kritis peserta didik diperoleh data pada setiap pertemuan yaitu pada pertemuan kelima sebesar 2,2 kriteria kritis dengan rata-rata perolehan kriteria ketuntasan belajar 79,42\% kriteria baik, pertemuan keenam sebesar 2,4 kriteria kritis dengan rata-rata perolehan kriteria ketuntasan belajar $88,83 \%$ kriteria sangat baik, pertemuan ketujuh 2,6 kriteria kritis dengan rata-rata perolehan kriteria ketuntasan belajar 91,33\% kriteria sangat baik. Secara keseluruhan pencapaian kemampuan berpikir kritis peserta didik dari setiap pertemuan dan tes evaluasi akhir siklus pada siklus II telah mencapai target yaitu kemampuan berpikir kritis mencapai rata-rata skor 2,4 kriteria kritis dengan rata-rata perolehan kriteria ketuntasan belajar yaitu $86,90 \%$ kriteria sangat baik.

Hasil kemampuan berpikir kritis peserta didik juga mengalami peningkatan dari ratarata perindikator pada setiap siklus I ke siklus II dapat dilihat pada Tabel 1.

Tabel 1. Peningkatan rata-rata perindikator kemampuan berpikir kritis peserta didik pada siklus I dan II

\begin{tabular}{lcc}
\hline $\begin{array}{c}\text { Rata-rata } \\
\text { Indikator } \\
\text { Kemampuan } \\
\text { Berpikir Kritis }\end{array}$ & $\begin{array}{c}\text { Siklus } \\
\text { I }\end{array}$ & $\begin{array}{c}\text { Siklus } \\
\text { II }\end{array}$ \\
\hline Mengidentifikasi & 2,1 & 3 \\
Mengklarifikasi & 1,8 & 2,3 \\
Menganalisis & 1,4 & 2 \\
fakta & 1,3 & 2 \\
Memecahkan masalah & 1,3 & 2,6 \\
Mengevaluasi & 2 & 2,9 \\
Menginferensiasi & & \\
\hline
\end{tabular}


Berdasarkan Tabel 1 di atas menunjukkan adanya peningkatan perolehan rata-rata skor kemampuan berpikir kritis peserta didik dari 1,7 meningkat menjadi 2,5 dengan penerapan model pembelajaran kooperatif tipe talking stick berbantuan media pohon matematika. Berdasarkan catatan lapangan dari hasil observasi aktivitas guru dan peserta didik juga menunjukkan pelaksanaan pembelajaran semakin menarik dan komunikatif.

Berdasarkan hasil analisis dan refleksi dari hasil aktivitas guru, aktivitas peserta didik, dan hasil kemampuan berpikir kritis, serta capaian kriteria ketuntasan belajar minimal juga menunjukkan tercapainya sesuai target yang diharapkan maka peneliti memutuskan untuk tidak melanjutkan tindakan dan evaluasi pada siklus berikutnya dan menyatakan bahwa penelitian ini telah berhasil.

Kemampuan berpikir kritis peserta didik dari seluruh indikator-indikator berpikir kritis diperoleh data dari penelitian ini bahwa peserta didik seluruhnya berada pada kategori kritis. Mengukur kemampuan berpikir kritis peserta didik merupakan kegiatan untuk menentukan bagaimana peserta didik dapat mengembangkan kemampuan yang ada dalam dirinya yang mendorong peserta didik untuk belajar secara mandiri. Belajar mandiri dimaksudkan bagi peserta didik untuk dapat memutuskan tujuan belajar, mempertimbangkan semua asumsi, merencanakan langkah-langkah ke arah gawang, serta memikirkan konsekuensi yang timbul dari setiap tindakan (Djiwandono, 2013).

Menanamkan konsep berpikir kritis pada memori peserta didik tentunya butuh arahan dan bimbingan, hal ini sesuai dengan pernyataan Subanji (2013: 14) bahwa dalam proses pendidikan, peserta didik dikatakan belajar jika guru mengajak peserta didik bernalar/berpikir dengan memberikan materi ajar yang relevan dengan usia peserta didik, tingkat perkembangan kognitif peserta didik, serta relevan dengan kehidupan peserta didik. Pemahaman berpikir harus sejalan dengan materi yang disampaikan dengan memberi konsep dasar materi. Konsep direalisasikan dalam bentuk belajar baik secara tim maupun individu dengan bantuan media pohon matematika dengan penyelesaian secara open ended. Menurut Basir (2018) melalui pendekatan open ended siswa dapat menemukan sesuatu yang baru dalam penyelesaian suatu masalah, khususnya masalah yang berkaitan dengan matematika. Dalam hal ini pendekatan open ended dapat diterapkan dalam proses pembelajaran dalam kelas di sekolah (Jahril, 2016).

Sa'dijah (2013) menambahkan bahwa untuk mengembangkan kemampuan berpikir kritis peserta didik secara logis dalam memecahkan masalah dan mengambil keputusan, diperlukan peran seorang guru, karena itulah maka guru herus memiliki kreatifitas dalam memberikan pembelajaran yang baik, inovatif, dan menyenangkan di dalam kelas.

\section{KESIMPULAN}

Berdasarkan kegiatan penelitian yang dilaksanakan dalam dua siklus, yaitu siklus I dan siklus II yang masing-masing melakukan 4 pertemuan, diperoleh kesimpulan bahwa pembelajaran dengan menggunakan model pembelajaran kooperatif tipe talking stick berbantuan media pohon matematika dapat meningkat.

Peningkatan kemampuan berpikir kritis peserta didik terlihat dari perolehan dari hasil tes berpikir kritis pada setiap tindakan pada siklus I dan II, serta hasil tes evaluasi akhir siklus I dan II dengan perolehan klasikal sebagai berikut:

1. Rata-rata hasil tes kemampuan berpikir kritis tiap tindakan siklus pada siklus I sebesar $69,14 \%$ meningkat signifikan pada siklus II sebesar $86,53 \%$.

2. Rata-rata hasil tes kemampuan berpikir kritis peserta didik dari hasil evaluasi akhir siklus I sebesar $60,42 \%$ meningkat signifikan pada siklus II sebesar $88,00 \%$.

Selain peningkatan hasil kemampuan berpikir kritis peserta didik, maka rata-rata perolehan untuk aktivitas guru dan peserta didik juga meningkat setiap tindakan dari 
setiap siklus pada siklus I dan II yaitu sebagai berikut:

1. Rata-rata aktivitas guru dalam pembelajaran pada siklus I sebesar $67,95 \%$ meningkat signifikan pada siklus II sebesar $89,10 \%$.

2. Rata-rata aktivitas peserta didik dalam pembelajaran pada siklus I sebesar $55,13 \%$ meningkat signifikan pada siklus II sebesar $82,05 \%$.

\section{DAFTAR RUJUKAN}

Arikunto, S., dkk. 2016. Penelitian Tindakan Kelas. Jakarta: PT Bumi Aksara.

Basir, F. 2018. Penerapan Pendekatan OpenEnded Dalam Pembelajaran Matematika Untuk Meningkatkan Kemampuan Berpikir Reflektif Siswa SMP. Jurnal Pedagogy. 3 (1). 148-155

Cahyaningsih, U,. \& Anik, G. 2014. Pengaruh Penggunaan Model Problem Based Learning terhadap Karakter Kreatif dan Berpikir Kritis dalam Pembelajaran Matematika. Jurnal Pendidikan Karakter. 6 (1).

Djiwandono, P. I. 2013. Critical Thinking Skills for Lenguage Students. TEFLIN Journal, Volume 24, Number 1.

Gokhale, A. A. 2002. Collaborative Learning Enhances Critical Thinking. http:// scholar. lib. vt. Edu/ enjournals/ JTE.

Hassoubah, I. Z.. 2004. Developing Creatif and Critical Thinking Skill (Cara Berpikir Kreatif dan Kritis). Nuansa: Bandung.

Huda, M. 2013. Model-model Pengajaran dan Pembelajaran. Yogyakarta: Pustaka Pelajar.

Jahril. 2016. Efektifitas Penerapan Pendekatan Open Ended Problem (OEP) Terhadap Hasil Belajar Matematika Peserta Didik Kelas VIII SMP Negeri 3 Binamu Kab. Jeneponto. Skripsi: Fakultas Tarbiyah dan Keguruan UIN Alauddin Makassar.

Kumullah, R., Djatmika, E. T., \& Yuliati, L. 2018. Kemampuan Berpikir Kritis dan Penguasaan Konsep Siswa dengan Problem Based Learning pada Materi Sifat Cahaya. Jurnal Pendidikan: Teori,
Penelitian, dan Pengembangan. 3 (12). 1583-1586

Peraturan Menteri Pendidikan dan Kebudayaan Nomor 103 tahun 2013 tentang Pembelajaran pada Pendidikan Dasar dan Menengah. Jaringan dokumentasi dan Informasi Hukum Kementerian Pendidikan dan Kebudayaan Republik Indonesia. (Online), (http://sdm.data.kemdikbud.go.id),

Prastowo, A. 2013. Pengembangan Bahan Ajar Tematik Panduan Lengkap Aplikatif. Yogyakarta: Diva Press.

Purwanto. 2013. Strategi Pembelajaran Bidang Studi Geografi. Cetakan kedua. Malang: Universitas Negeri Malang (UM Press).

Redhana, I. 2003. Meningkatkan Keterampilan Berpikir Kritis Siswa Melalui Pembelajaran Kooperatif Dengan Strategi Pemecahan Masalah. Jurnal Pendidikan Dan Pengajaran XXXVI. II: 11-21.

Sa'dijah, C. 2013. Kepekaan Bilangan Siswa SMP melalui Pembelajaran Matematika Kontekstual yang Mengintegrasikan Keterampilan Berpikir Kreatif. Jurnal Pendidikan dan Pembelajaran, 20 (2).

Smaldino, Lowter, dan Russel. 2011. Intructional Technology \& Media for Learning. Jakarta: Kencana Prenada Media Group.

Subanji. 2013. Pembelajaran Matematika Kreatif dan Inovatif. Malang: UM Press.

Sudjana, N. 2012. Penilaian Hasil Proses Belajar Mengajar. Bandung: Remaja Rosdakarya.

Wahidmuini. 2010. Pengembangan Kurikulum: IPS Ekonomi di Sekolah Madrasah. Malang: UIN-Maliki Press.

Yulianto, A., Asrul., Amirah, S. 2018. Proses Pembelajaran Operasi Pengurangan Berbantuan Media Tabung Pengurangan Pada Kelas I SDN Mojolangu 3. Jurnal Ilmu Pendidikan Dasar: Dikdas Matappa. 1 (2). 158-165 